\title{
Studies on decreasing Chemical Oxygen Demand (COD) on artificial laundry wastewater using anaerobic-aerobic biofilter dipped with bio ball media
}

\author{
Netti Herlina ${ }^{1 *}$, Muhammad Turmuzi Lubis ${ }^{2}$, Amir Husin ${ }^{1}$, and Ihmawani Putri ${ }^{1}$ \\ ${ }^{1}$ Department of Environmental Engineering, Universitas Sumatera Utara, Medan, Indonesia \\ ${ }^{2}$ Department of Chemical Engineering, Universitas Sumatera Utara, Medan, Indonesia
}

\begin{abstract}
This study aims to determine the effect of discharge variation on the efficiency of decreasing COD parameters contained in artificial laundry wastewater. In this study used a combination of two biofilter reactor dipped with bio ball media with each condition that is anaerobic and aerobic. Drainage of waste carried out continuously and upflow is the direction of the streamline. The research begins with seeding phase which aims to grow microorganisms derived from domestic IPAL sludge unit then followed by acclimatization phase which aim to adapt microorganism with artificial laundry wastewater. After the acclimatization phase is completed, the running process starts by operating three variations of discharge that is $0.625 \mathrm{l} / \mathrm{hr}, 0.833 \mathrm{l} / \mathrm{hr}$, and $1.25 \mathrm{l} / \mathrm{hr}$. The results showed that the operation of the three variations of discharge did not give a significant influence in setting aside the COD parameters. The percentage of COD removal achieved by each of these debit operations is $82 \%, 83 \%$, and $81 \%$. In addition, the combination of anaerobic and aerobic dipped biofilter is also able to eliminate surfactant and TSS with the achievement of $90 \%$ average removal percentage.
\end{abstract}

\section{Introduction}

A large number of activities that develop in urban areas as a result of the rapid growth of population and the demands of comfort has brought changes to the lifestyle of society. The community is no longer able to do some household activities independently due to the higher hours of work and activities undertaken. This busy working culture has resulted in people dependency in service businesses that assist them in completing house chores is getting higher, especially in laundry services [1].

The increasing number of laundry business will undoubtedly result in the increasing volume of wastewater generated. Increasing the amount of laundry wastewater will cause problems in the waters when it discharged into the water body without processing. Until

\footnotetext{
*Corresponding author: cecesrg@yahoo.com
} 
now almost all the laundry industry directly dispose of waste into drainage channels or water bodies without going through the processing first $[2,3]$.

Laundry wastewater is one of the types of wastewater that pollutes many water bodies [4]. It is because laundry wastewater contains many chemicals such as phosphates, surfactants, ammonia, nitrogen, Total Suspended Solid (TSS), turbidity, Biological Oxygen Demand (BOD) and Chemical Oxygen Demand (COD) with high concentrations [5].

The increasing amount of laundry will undoubtedly lead to an increase in the concentration of COD with the potential to pollute water bodies. The high content of COD in waters will result in the disturbance of the water ecosystem, decreased water quality and reduced the ability of self-purification of waters [6].

Wastewater treatment methods can be done physically, chemically and biologically [4]. The application of biological waste treatment is chosen because it is effective and inexpensive by utilizing the abundant microbial capabilities in nature [7, 8]. Biological laundry wastewater treatment can be done using biofilter technology. There are many studies on laundry wastewater treatment using biofilter technology with various types of filter media such as plastic fiber and pottery [1] and stone media times [9]. Biofilter technology is widely developed due to its easy management and efficiency removal of nutrient content and good organic material [10].

In this study used the combination of anaerobic and aerobic biofilter reactor with the principles of microbial growth and attached on bio ball filter media and can be applied to treat wastewater laundry industry.

\section{Research methodology}

\subsection{Research object and biofilter media}

The object of research is synthetic laundry wastewater created from a mixture of powdered detergent and water with a concentration of $1.15 \mathrm{~g} / \mathrm{l}$.

The media used in this research is biological filter media namely bioball which is included in the type of random filter media or dumped packing. The advantages of this media such as have a large active surface area, has a spherical design, so it is easy to fill the filtration space optimally even though the placement is random, low weight, has a good cavity fraction, eliminates problems relating to clogging and durable to use. There are many types and sizes of bioball on the market [11]. In this research, used bio ball media in the form of black colored balls made of plastic material. Bio ball used has a diameter of 25 $\mathrm{mm}$. Images of bio ball media can be seen in Fig. 1.

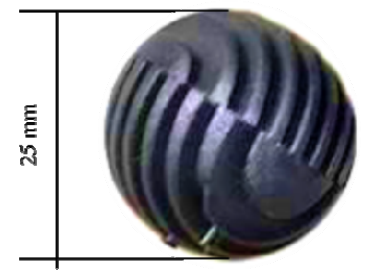

Fig. 1. Bio ball media.

\subsection{Reactor model}

In this research, waste treatment is done by operating the reactor circuit consisting of the reservoir as the synthetic laundry wastewater container, the anaerobic biofilter reactor, and the aerobic biofilter reactor. The specifications of the reactor circuit can be seen in Table 1 . 
Table 1. Reactor reference specification.

\begin{tabular}{|c|c|c|}
\hline & Description & Explanation \\
\hline \multirow[t]{2}{*}{ Reservoir } & Material & Plastic \\
\hline & Volume & 150 Liter \\
\hline \multirow[t]{6}{*}{ Anaerobic reactor } & Material & Glass, $5 \mathrm{~mm}$ diameter \\
\hline & Height & $50 \mathrm{~cm}$ \\
\hline & Length & $30 \mathrm{~cm}$ \\
\hline & Width & $35 \mathrm{~cm}$ \\
\hline & Media height & $35 \mathrm{~cm}$ \\
\hline & Processing capacity & 40 liter \\
\hline \multirow[t]{6}{*}{ Aerobic reactor } & Material & Glass, $5 \mathrm{~mm}$ diameter \\
\hline & Height & $50 \mathrm{~cm}$ \\
\hline & Length & $25.5 \mathrm{~cm}$ \\
\hline & Width & $20.5 \mathrm{~cm}$ \\
\hline & Media height & $35 \mathrm{~cm}$ \\
\hline & Processing capacity & 20 liter \\
\hline
\end{tabular}

Artificial laundry wastewater that stored in the reservoir flows to the anaerobic reactor. The run-off water that out of the anaerobic reactor outlet is then flowed into the aerobic reactor. In each reactor unit will be filled with bio ball media with $35 \mathrm{~cm}$ height (It takes around 1600 pcs of bioball for anaerobic reactors and 800 pcs of bioball for aerobic reactors), and the height of mud space, water height above the media surface and airspace height that is $5 \mathrm{~cm}$ each.

The inlet reactor is an infusion tube inserted through the top of the reactor so that an upflow flow direction which is expected to flow will cause the wastewater to contact evenly on the surface of the bio ball medium. The outlet reactor is an infusion tube located at the top of the reactor. In the reactor will be made of insulation on the side that serves to separate the space between the inlet hose with the media bed space. This is done so that the flow of wastewater will not disrupt the biofilm that is formed. Also, the partition is also made at the bottom that serves to support the media and separates between the media bed and the mud space. The oxygen supply in the aerobic reactor uses an aerator mounted on the bottom and side of the media. Each reactor has two bulkheads which serve to separate the media from the inlet channel and separate the media from the mud space. The flow direction used in the reactor is an upflow stream with an inlet line inserted through the top of the reactor, and the outlet channel is at the top of the media.

\subsection{Seeding process}

The process of seeding is done by soaking the bio ball media that has been inserted into the anaerobic and aerobic biofilter reactor with a mixture of mud and wastewater generated 
from domestic wastewater unit. This seeding stage is carried out with the batch mode of operation. The seeding process was carried out for 21 days for the anaerobic reactor and 22 days for the aerobic reactor. The aerobic reactor's aeration is conducted continuously. Examination in the seeding stage is done visually by looking at the appearance of the biofilm layer on bio ball media and COD examination on each reactor. Also, $\mathrm{pH}$ and Temperature were examined at each reactor. The addition of a substrate of sugars (sucrose) to the reactor at any time if required when low COD or biofilm appears to decay.

\subsection{Acclimatization process}

Acclimatization is done by replacing domestic wastewater used in seeding with artificial laundry water. Acclimatization process is done continuously. The acclimatization stage is technically done by draining the synthetic laundry wastewater stored in the reservoir to the biofilter reactor circuit as much as $10 \%$ of the total water volume of the two reactors then gradually domestic wastewater will be replaced $100 \%$ with laundry wastewater every day for ten days. COD checks are performed at the stage for each reactor. At this stage, it is expected that the biofilms formed will be thickened which indicates that microorganisms have adapted to synthetic laundry wastewater. Stages of acclimatization is in Table 2.

Table 2. Stages of acclimatization.

\begin{tabular}{|c|c|c|}
\hline Stages & IPAL sludge (\%) & Artificial laundry wastewater (\%) \\
\hline Stage 1 & 90 & 10 \\
\hline Stage 2 & 80 & 20 \\
\hline Stage 3 & 70 & 30 \\
\hline Stage 4 & 60 & 40 \\
\hline Stage 5 & 50 & 50 \\
\hline Stage 6 & 40 & 60 \\
\hline Stage 7 & 30 & 70 \\
\hline Stage 8 & 20 & 80 \\
\hline Stage 9 & 10 & 90 \\
\hline Stage 10 & 0 & 100 \\
\hline
\end{tabular}

\subsection{Running process}

The running process is done with a continuous operation mode. In the operating process used three variations of the discharge that has been adjusted with each reactor HRT. Here are three variations of the discharge will be used as presented in Table 3.

The replacement of the discharge is carried out after the operation is run for seven days and sampling is done every day and performed on two sampling points. The two sampling points are anaerobic reactor effluent and aerobic reactor effluent. Furthermore, an analysis of COD parameters was performed on each reactor. For the surfactant and TSS test samples were performed on the last day of operation of the discharge variation and the location of the sampling point at the outlet of the aerobic reactor. 
Table 3. Discharge variation $(\mathrm{Q})$.

\begin{tabular}{|c|c|c|}
\hline \multirow{2}{*}{ Q (l/hour) } & \multicolumn{2}{|c|}{ HRT (hour) } \\
\cline { 2 - 3 } & Anaerobic & Aerobic \\
\hline 0.625 & 64 & 32 \\
\hline 0.833 & 48 & 24 \\
\hline 1.25 & 32 & 16 \\
\hline
\end{tabular}

\section{Results and discussion}

\subsection{Wastewater characteristics}

The waste used in this research is artificial wastewater with laundry wastewater characteristics. The reason for the use of artificial wastes due to research carried out for an extended period so that it requires a large volume of wastewater. Moreover, the quality of synthetic wastewater can also be more controlled. Characteristics of the synthetic laundry wastewater used in the study can be seen in Table 4.

Table 4. Characteristics of artificial laundry wastewater.

\begin{tabular}{|l|c|c|c|c|}
\hline Parameter & Unit & Concentration & Quality standards & Information \\
\hline COD & $\mathrm{mg} / 1$ & 671 & $100-300^{[12]}$ & Exceeded \\
\hline Phosphate & $\mathrm{mg} / 1$ & 11 & - & Not set \\
\hline $\mathrm{pH}$ & - & 9.5 & $6-9^{[12]}$ & Exceeded \\
\hline Surfactant & $\mathrm{mg} / 1$ & 150 & $5-10^{[13]}$ & Exceeded \\
\hline TSS & $\mathrm{mg} / 1$ & 95 & $30^{[12]}$ & Exceeded \\
\hline
\end{tabular}

Based on the table above, it can be seen that synthetic laundry wastewater used in this study has a concentration of parameters that entirely exceed the quality standard specified in Permen LH. 5/2014 and PermenLHK No. 68/2016. Phosphate parameters do not have a quality standard outlined in national regulations, then COD became the parameter tested.

\subsection{Seeding results}

Based on observations made during the seeding stage, the brownish thin film on the medium in the aerobic reactor starts to appear on day 2, and a thin black film on the medium in the anaerobic reactor begins to appear on day 6. According to [14], the formation of a black colored brownish slime layer and not easily separated from the media indicate that the microorganisms have been grown on the media. During the seeding process takes place, biofilm steadily thickening. This is shown from the surface of the media that almost entirely covered by the biofilm layer. The biofilm layer in the aerobic reactor appears thicker and more comparable to the biofilm layer in the anaerobic reactor, 
which indicates that the growth of microorganisms in aerobic conditions occurs more rapidly than in anaerobic conditions. According to [15], Reactors with aerobic conditions have a higher increase of microorganisms than anoxic or anaerobic. This is because the microorganisms that use dissolved oxygen (DO) for the assimilation process of new microorganisms get more energy than using bound oxygen. In addition to the formation of biofilms, the anaerobic reactor also appears gas bubbles that appear in the crevices of the bio ball medium and the surface of the reactor glass cover. According to [16], the emergence of bubbles of gas on the surface of the water shows the gas content of $\mathrm{CH}_{4}, \mathrm{CO}_{2}$, and other gases have been formed from the process of fermentation of organic materials by anaerobic bacteria.

The biofilm characteristics of each reactor also appear different. Biofilms in blackcolored anaerobic reactors with slightly rougher (grainy) visible texture are coating the surface of the bio ball medium. According to [17], characteristics of the biofilm that grows in anaerobic conditions seen black colored, more rugged and compact. Biofilm in aerobic reactor looks brownish color with the texture that looks more slippery and thicker coated the surface of bio ball media.

The optimum $\mathrm{pH}$ and temperature conditions are also factors affecting the breeding of microorganisms. In this study, the $\mathrm{pH}$ and temperature conditions of each reactor were not conditioned factors. The result of $\mathrm{pH}$ measurement on anaerobic condition shows the value of 5-6.9 and in aerobic condition shows value 6.5-7.8. According to [11], each type of microorganisms requires a specific $\mathrm{pH}$ to grow correctly. In general, microorganisms have growth conditions with a $\mathrm{pH}$ range between 4-9.5 with an optimum $\mathrm{pH}$ of 6.5 to 7.5. According to [18], the anaerobic process works most effectively in the $\mathrm{pH}$ range of 6.5-7.5 and the aerobic process works optimum in the $\mathrm{pH}$ range of 6.5-8.5. While the result of temperature measurement at the anaerobic condition that is $31-34^{\circ} \mathrm{C}$ and at the aerobic condition that is $30-32^{\circ} \mathrm{C}$. According to [19], bacteria can live and breed optimally in the temperature range $25-35^{\circ} \mathrm{C}$. Thus, the $\mathrm{pH}$ and temperature obtained still support bacterial growth in the biofilter.

The COD analysis was performed to determine the decrease in organic matter and the increase of microorganisms in the reactor [20], Based on the results of COD analysis on the anaerobic reactor, obtained the initial COD value of IPAL sludge used in the anaerobic reactor is $621 \mathrm{mg} / \mathrm{l}$. Changes in COD values of anaerobic reactors during the first week of operation (Days 1, 4 and 6) continued to increase. The increase in COD values that occur is thought to be due to an increase in biomass of microorganisms. According to [21] the rise of biomass is caused by the growth of microorganisms in the waste. The increase in COD value is caused by the increasing number of biomass that is formed due to the increase of cell so that organic material that must be degraded will increase by itself. The fluctuation of COD value is directly proportional to the rise of cells. The COD value rises as the cell number tends to rise [22]. On the $7^{\text {th }}$ day and the $14^{\text {th }}$ day, sugar was given as much as $1 \mathrm{~g} / 1$ as a carbon source for microorganisms. On day 8 to day 21 , the value of COD continues to decline with the highest efficiency occurring on day 15 by $22 \%$. For aerobic reactors, changes in COD values occur voluntarily during seeding. The initial COD value of the IPAL sludge used in the aerobic reactor was $909 \mathrm{mg} / \mathrm{l}$. On the first day of seeding, there was a decrease in COD value by $24 \%$. Furthermore, there was a drastic increase of COD on the $2^{\text {nd }}$ day by $96 \%$ and COD value decreased on the 5 th day and the 7 th day. The COD value increased on the 9 th day until the $13^{\text {th }}$ day. According to [23] that during the seeding period, the aerobic reactor will remain in a non-steady state until the biofilm fully developed. After day 16 the COD values continued to decline until the $22^{\text {nd }}$ day. This decrease indicates that the formation of the biofilm layer on bio ball media is accompanied by the degradation of organic compounds. Based on visual observations and reduced COD 
value suggests that the seeding process has been successful. The following chart seeding results in each reactor can be seen in Fig. 2 and 3.

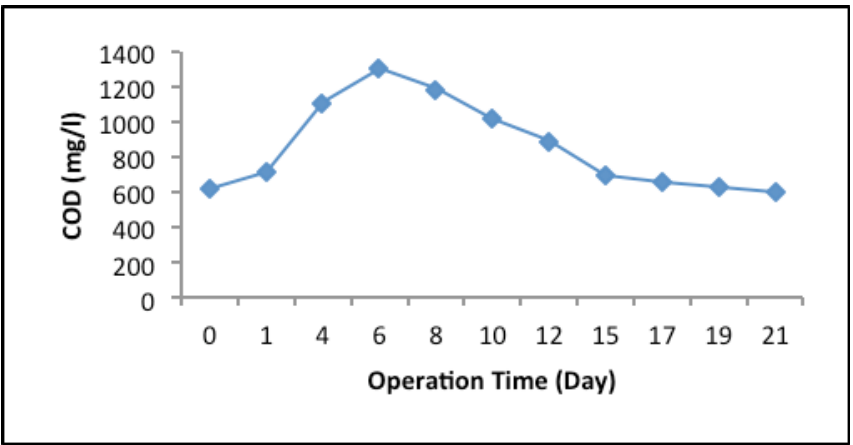

Fig. 2. Results of COD seeding analysis (Anaerobic).

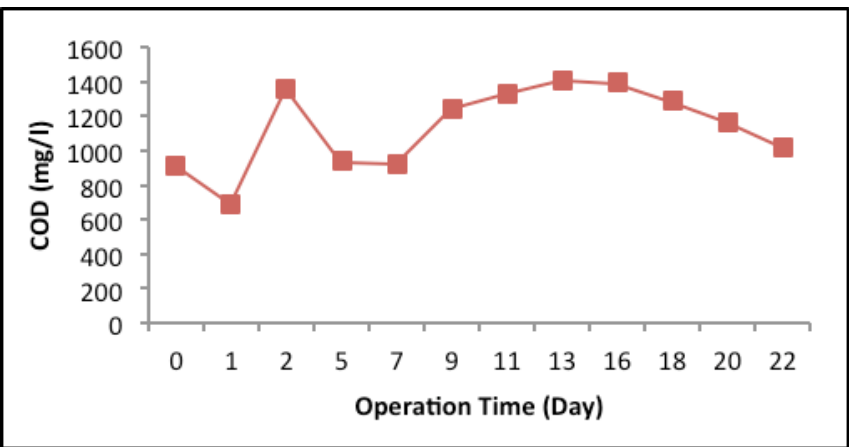

Fig. 3. Results of COD seeding analysis (Aerobic).

\subsection{Acclimatization results}

In this research, the COD value in artificial laundry water influent is $671 \mathrm{mg} / \mathrm{l}$. At the time of acclimatization lasts for four stages, effluent COD value in the anaerobic reactor and aerobic reactor still fluctuate. The value of COD in the anaerobic reactor is even increasing from the influent value within four days of acclimatization time. The occurrence of fluctuations in the value of COD in each reactor may be due to microorganisms have not been able to adapt to the added volume of synthetic laundry wastewater in each stage.

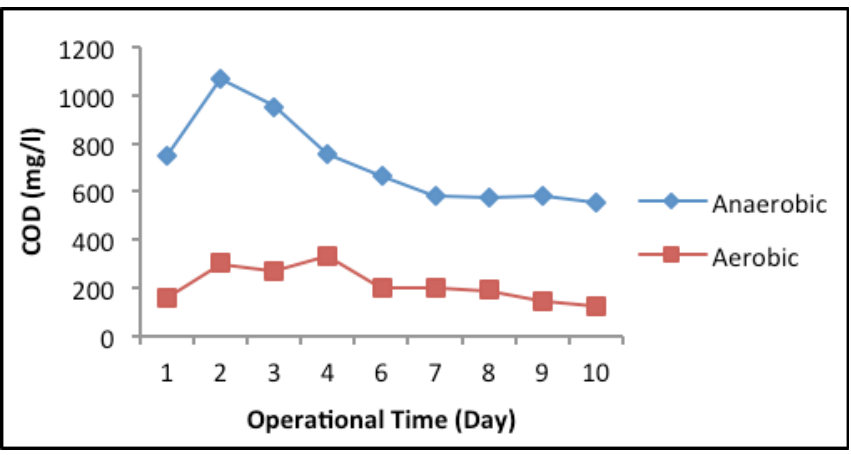

Fig. 4. Results of COD analysis of acclimatization process. 
According to [24], direct feeding at large concentrations of bacteria that are still vulnerable and not many will result in shock loading because bacteria have not been able to degrade organic materials. Bacteria also cause concentrations of effluents that have elevated COD values in shock with the addition of food. The decrease of COD value on each reactor started to occur on the 6th day of operation time and generally decreased until the 10th day. Graph of COD value reduction in the acclimatization process is in Fig. 4.

For a total COD reduction efficiency (Anaerobic and Aerobic Combinations), in comparison of synthetic laundry wastewater with 10\%: $90 \%$ domestic waste, the total COD removal efficiency was $77 \%$. The removal percentage of COD values decreased during the $2^{\text {nd }}$ and $4^{\text {th }}$ day operation, yet it increased again in each stage during the 6th day to the 10th day. At the time the influent had been $100 \%$ replaced with artificial laundry waste, i.e., after 10 day operating time, the total removal efficiency of COD reached $82 \%$. This is directly proportional to the visual observation of biofilms on each reactor which seems to be getting thickened along with the acclimatization phases. According to [25], increased efficiency of COD removal indicates the presence of microorganisms that have grown and degrade organic compounds contained in the wastewater. Graph of COD value reduction efficiency in the acclimation process can be seen in Fig. 5.

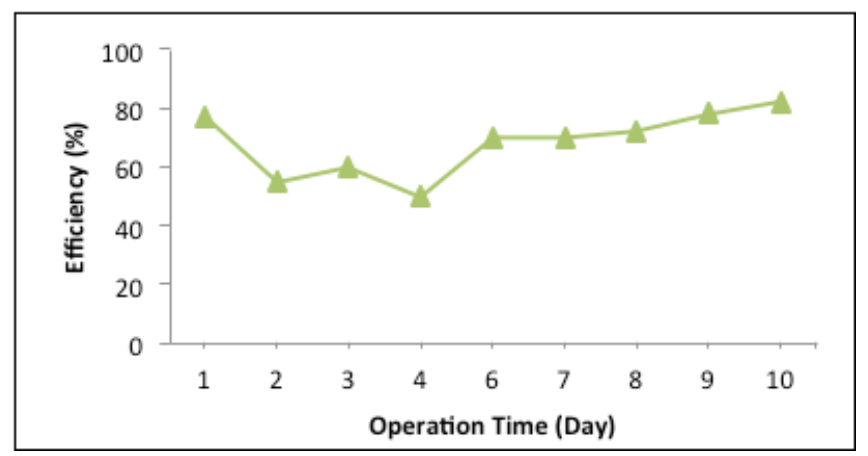

Fig. 5. Total efficiency of COD degradation of acclimatization process.

The $\mathrm{pH}$ and temperature conditions of each reactor during the acclimation process are not significantly changed. For $\mathrm{pH}$ measurements, the two reactors are considered capable of reducing the $\mathrm{pH}$ of synthetic laundry wastewater with an initial value of 9.5. The decrease in $\mathrm{pH}$ shows that in the anaerobic reactor there is a process of fermentation of organic material contained in artificial wastewater made by bacteria so that the $\mathrm{pH}$ can decrease with the $\mathrm{pH}$ range obtained is 5.8-7.8. In the aerobic reactor, the $\mathrm{pH}$ range obtained was 7.1-7.6. According to [26], the optimum $\mathrm{pH}$ of most bacteria is 6.5 to 7.5 , and the minimum and maximum $\mathrm{pH}$ values for most bacterial species are 4 and 9. For temperature measurements, the temperature range obtained during acclimatization in the anaerobic reactor is $30-31{ }^{\circ} \mathrm{C}$ and obtained at the aerobic reactor, i.e., 29-31 ${ }^{\circ} \mathrm{C}$. According to [19] bacteria can live and breed optimally in the temperature range $25-35^{\circ} \mathrm{C}$.

\subsection{Running results}

The running process begins with a discharge of $0.833 \mathrm{l} / \mathrm{h}$, followed by a discharge of 1.25 $\mathrm{l} / \mathrm{h}$ and ends with a discharge operation of $0.625 \mathrm{l} / \mathrm{hr}$.

\subsubsection{COD allowance}

For discharge $0.8331 / \mathrm{hr}$ with the average efficiency of total COD removal reached $83 \%$, for $0.625 \mathrm{l} / \mathrm{hr}$ discharge with the average efficiency of total COD removal of $82 \%$, and for 1.25 
1/h discharge with total COD removal efficiency decreased to about $81 \%$. Based on the results of the experiment it is discovered that the greatest COD removal efficiency occurs at $0.833 \mathrm{l} / \mathrm{h}$ discharge with HRT $48 \mathrm{~h}$ in the anaerobic reactor and $24 \mathrm{~h}$ in the aerobic reactor. Meanwhile, according to [27], the smaller the flow of wastewater, the more HRT wastewater in the reactor and this can increase the efficiency of the allowance. Different results obtained in the results of this experiment may be due to the operation of the change of discharge variation not done sequentially from the smallest discharge to the most massive discharge. The running process starts from the next $0.833 \mathrm{l} / \mathrm{h}$ of discharge after seven days, replaced by the use of $1.25 \mathrm{l} / \mathrm{h}$ of discharge for seven days and continued with the use of $0.625 \mathrm{l} / \mathrm{h}$ of discharge. Substitution of discharge values that not aligned may cause the biofilm contained in the reactor to be unable to adapt well as the hydraulic loads are inflated. According to [25], the change in flow discharge to be smaller than the previous operation may lead to a decrease in efficiency caused by the adaptation of microorganisms grown in the biofilter reactor to larger hydraulic loads.

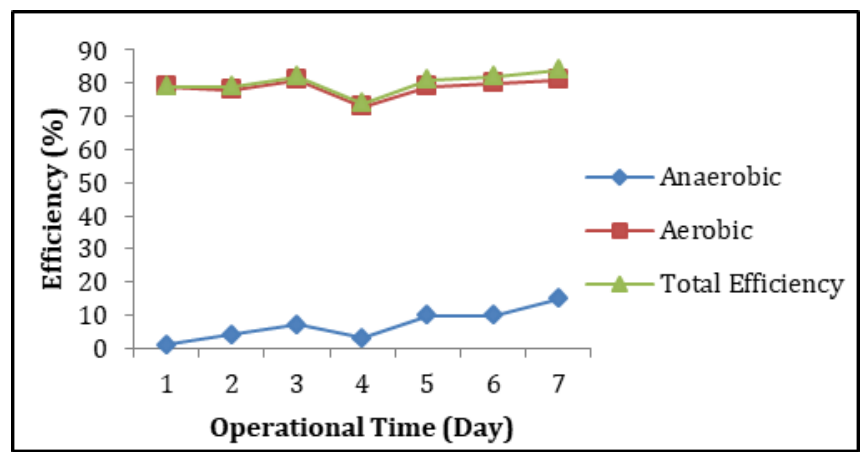

Fig. 6. Efficiency of COD decrease $(\mathrm{Q}=0.625$ 1/hour $)$.

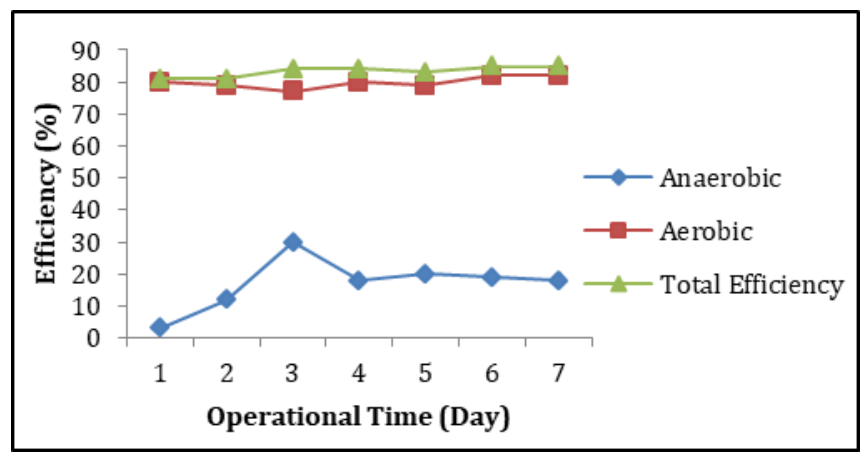

Fig. 7. Efficiency of COD decrease $(\mathrm{Q}=0.833$ 1/hour $)$.

From the experimental results, it is also known that organic pollutant removal (COD) mostly occurs in an aerobic biofilter reactor. In the aerobic biofilter reactor, the efficiency of COD removal for the three variations of the discharge ranged from 73 to $81 \%$. While for the total efficiency of COD removal for three varieties of the discharge ranged between 74$85 \%$. Based on these data it can be concluded that the aerobic zone contributes significantly to COD removal and the anaerobic zone is known to contribute only about $11 \%$ of the overall COD removal by the combination of the biofilter. Various factors can cause the low efficiency that can be achieved by anaerobic reactors. One of the factors is the nonconformity of COD values found in wastewater to be treated with anaerobic conditions. According to [28], the minimum concentration of influent COD needed to achieve success 
in anaerobic treatment is $1000 \mathrm{mg} / \mathrm{l}$. Through the anaerobic process, it is expected that complex organic compounds can be decomposed into pure organic compounds. If the COD value is less than $1000 \mathrm{mg} / \mathrm{l}$, then only the aerobic process is needed to reduce the COD value in the wastewater. In this experiment, the COD values in the influent used were categorized as low which is $671 \mathrm{mg} / \mathrm{l}$. The efficiency of COD removal for each discharge variation can be seen in Fig. 6, 7 and 8.

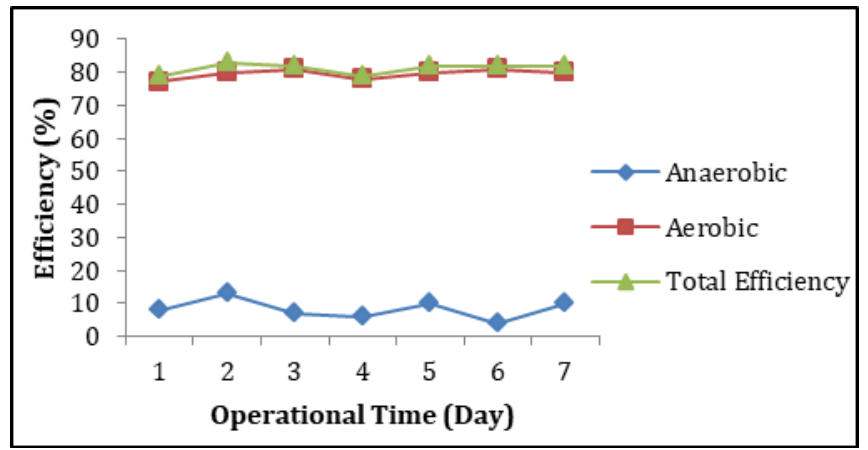

Fig. 8. Efficiency of COD decrease $(\mathrm{Q}=1.25$ 1/hour $)$.

\subsubsection{Surfactant allowance and Total Suspended Solid (TSS)}

In this experiment also tested the parameters of the surfactant and Total Suspended Solid (TSS). Tests on both parameters are only performed on each of the last days of operation of the discharge and sampling variations only on the effluent of the aerobic reactor. This is done to determine the value of surfactant and TSS removal obtained from the combination of both reactors. The results of surfactant and TSS analyzes can be seen in Fig. 9 and 10.

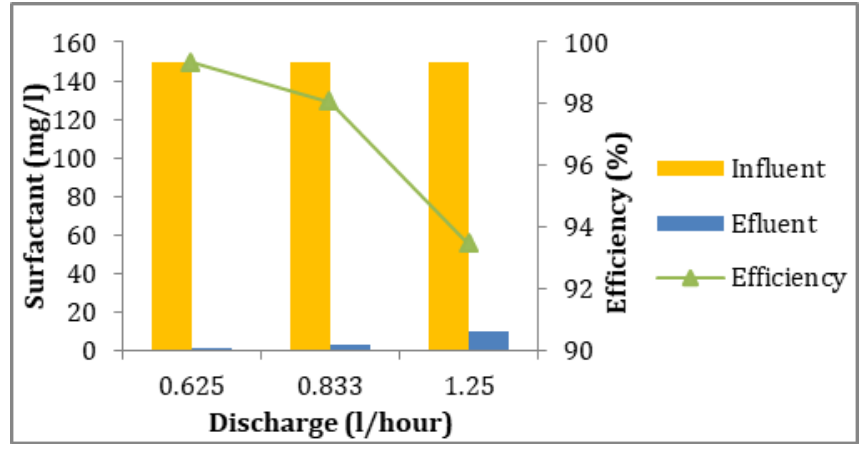

Fig. 9. Surfactant decreasing efficiency.

Based on the test result on surfactant and TSS parameters it is known that both of them have decreased concentration on each operation of discharge variation that had been done. The efficiency of the surfactant decrease from the three varieties of the discharge reaches $90 \%$ removal percentage. The highest removal percentage was obtained when the discharge operation was $0.625 \mathrm{l} / \mathrm{h}$ which is $99 \%$ with the concentration of surfactant to $1.0 \mathrm{mg} / \mathrm{l}$ from the initial concentration of surfactant $150 \mathrm{mg} / \mathrm{l}$. For the discharge of $0.833 \mathrm{l} / \mathrm{h}$ and $1.25 \mathrm{l} / \mathrm{h}$, the percentage of surfactant removal obtained was $98 \%$ and $93 \%$. The percentage value of the surfactant removal decreases with the higher the discharge operated. This shows that the smaller the discharge made contact that occurs between the time the wastewater with biofilm is getting long, so the chance of microorganisms to degrade the surfactant contained 


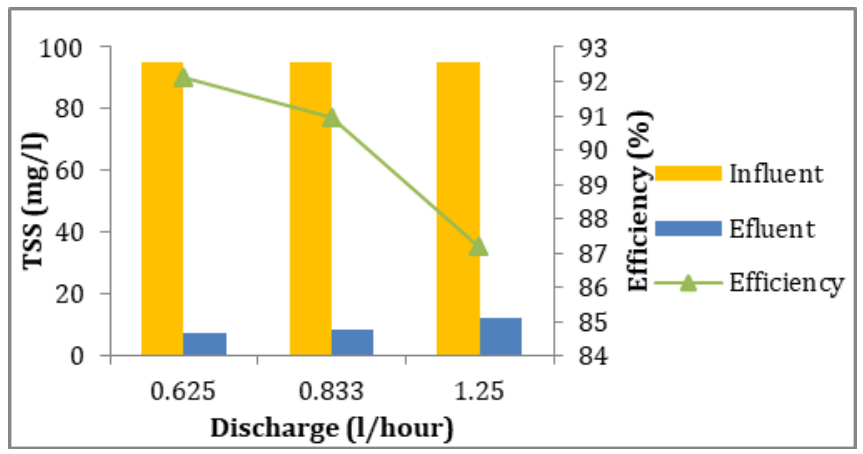

Fig. 10. Total suspended solid (TSS) decrease efficiency.

in the wastewater increases. According to [27] the smaller the flow of wastewater, the higher the residence time of wastewater in the reactor. This will cause the contact time between the wastewater with microorganisms is getting longer and make the surfactant removal efficiency becomes greater. Also, according to [29] the reduction of surfactant content in wastewater in aerobic biofilter can also be due to the flotation process which is the direct effect of blowing air bubbles. In this experiment, an aerator is used to supply air in the anaerobic reactor.

The percentage of TSS removal obtained from the operation of the three discharges also reached $90 \%$. The best decrease efficiency of TSS parameters was achieved in the smallest, $0.625 \mathrm{l} / \mathrm{h}$, discharge operation which is $92 \%$ with TSS concentration to $7.5 \mathrm{mg} / \mathrm{l}$ from the initial concentration of $95 \mathrm{mg} / \mathrm{l}$. For the discharge of $0.833 \mathrm{l} / \mathrm{h}$ and $1.25 \mathrm{l} / \mathrm{hr}$, the percentage of surfactant removal obtained was $91 \%$ and $87 \%$. According to [30], the longer the contact time of wastewater with the biofilter media, the inorganic suspended substance is filtered by the media and that is organic will be degraded by biofilm that stick to the surface of the media so that it will get the water of the processing which is more improved quality.

\section{Conclusions}

The conclusions obtained from this research are as follows. The use of a combination of anaerobic and aerobic biofilter reactors with bio ball media is known to decrease COD, Surfactant and Total Suspended Solid (TSS) parameters contained in artificial laundry water. In general, the operation of the three variations of discharge of $0.625 \mathrm{l} / \mathrm{h}, 0.833 \mathrm{l} / \mathrm{h}$ and $1.25 \mathrm{l} / \mathrm{h}$ on the combination of anaerobic and aerobic biofilter reactors did not have a significant effect in excluding COD, Surfactant and TSS parameters. The percentage of COD removal achieved by each discharge is $82 \%, 83 \%$, and $81 \%$. Percentage of surfactant removal achieved by each of the discharge is $99 \%, 98 \%$, and $93 \%$. The percentage of TSS removal achieved by each of these discharges is $92 \%, 91 \%$, and $87 \%$. Based on the results of the test on the effluent of anaerobic and aerobic combination processing with bio ball media, the three parameters for COD, Surfactant and TSS parameters have met the quality standard attached to PerMen LH No. 5/2014 and PerMen LHK No. 68/2016.

\section{References}

1. S.Y. Nugroho, S. Sumiyati, M. Hadiwidodo, Jurnal Teknik Lingkungan 3, 2 (2014)

2. D.Y. Rustanto, N. Karnaningroem, Pros. Sem. Nas. Manajemen Tek. XVI (2012)

3. I.W. Wardhana, D.S. Handayani, D.I. Rahmawati, Teknik 30, 1 (2009)

4. N.G.A.D.A. Suastuti, I.W. Suarsa, D.K. Putra, Jurnal Kimia 9, 1 (2015) 
5. J. Ahmad, H. El-Dessouky, Resources, Conserv. and Recyc. 52, 7 (2008)

6. A.P. Rakhmawati, N. Karnaningroem, Pros. Sem. Nas. Manajemen Tek. XVI (2012)

7. H. Insam, I.F. Whittle, M. Goberna, Microbes at Work (Springer, Berlin, 2010)

8. H.B. Sutanto, Studi pengolahan air limbah industri jasa laundry menggunakan kombinasi biofilter dan tanaman bambu air (Universitas Kristen Duta Wacana, Yogyakarta, 2015)

9. S.P.P. Nasution, Pemulihan kualitas air limbah laundry dengan reaktor biofilter (Institut Teknologi Sepuluh Nopember, Surabaya, 2013)

10. N.I. Said, Pengelolaan air limbah domestik di DKI Jakarta- Tinjauan permasalahan, strategi dan teknologi pengolahan (Pusat Teknologi Lingkungan, Jakarta Pusat, 2008)

11. N.I. Said, Teknologi pengolahan air limbah teori dan aplikasi (Erlangga, Jakarta, 2017)

12. Pemerintah Republik Indonesia, Peraturan Menteri Lingkungan Hidup dan Kehutanan no. P.68/Menlhk/Setjen/Kum. 1 tahun 2016 tentang Baku Mutu Air Limbah Domestik (Menteri Lingkungan Hidup dan Kehutanan RI, Jakarta, 2016)

13. Pemerintahan Republik Indonesia. Peraturan Menteri Lingkungan Hidup no. 5 tahun 2014 tentang Baku Mutu Air Limbah (Menteri Lingkungan Hidup, Jakarta, 2014)

14. M. Filliazati, I. Apriani, T.A. Zahara, J. Tek. Lingkungan Lahan Basah 1, 1 (2013)

15. N.R. Jusepa, W. Herumurti, Jurnal Teknik ITS 5, 2 (2016)

16. D. Wulandari, R. H. Marlitasari, Proses Pengolahan Limbah Cair Domestik secara Anaerob, (Universitas Diponegoro, Semarang, 2011)

17. A. Æsøy, M. Storfjell, L. Mellgren, H. Helness, G. Thorvaldsen, H. Odegaard, G. Bentzen, Water Sci. and Tech. 36, 1 (1997)

18. W.W. Eckenfelder, J.B. Patoczka, G.W. Pulliam, Proc. of the $5^{\text {th }}$ International Symposium on Anaerobic Digestion (1988)

19. G. Tchobanoglous, F. L. Burton, H. D. Stensel, Wastewater Engineering: Treatment and reuse (McGraw Hill, New York, 2003)

20. M. Dworkin, S. Falkow, E. Rosenberg, E. K. Schleifer, E. Stackebrandt, The prokaryotes third edition-symbiotic association, biotechnolog (Springer-Verlag, New York, 2006)

21. B.S.L. Jenie, W.P. Rahayu, Penanganan limbah industri pangan (Kanisius, Yogyakarta, 1993)

22. Carolina, Sriharti, Neni, Pros. Sem. Perhimpunan Biotek. Pertanian Indonesia (2012)

23. M. Martinov, D. Hadjiev, S. Vlaev, Bioresource Technology 101 (2010)

24. Indriyati, Jurnal Teknik Lingkungan 2 (2003)

25. N.I. Said, Jurnal Air Indonesia 1, 1 (2005)

26. M.J. Pelczar, E.C.S. Chan, Dasar-dasar mikrobiologi 1 (UI Press, Jakarta, 1986)

27. I.K.T. Suarbawa, M. Ali, Jurnal Ilmiah Teknik Lingkungan 6, 2 (2016)

28. R.L. Droste, Theory and practice of water and wastewater treatment (John Wiley and Son, Canada, 1996)

29. N.I. Said, Ineza, Uji performance pengolahan air limbah rumah sakit dengan proses biofilter tercelup (Pusat Pengkajian dan Penerapan Teknologi Lingkungan, Jakarta, 2002)

30. A. Sani, M. Yani, Suprihatin, Optimasi proses biofilter skala pilot dengan media batu apung dalam upaya peningkatan kualitas air baku (IPB, Bogor, 2017) 